\title{
Critical Analysis of the Emergency Program for the Acceleration of the Reform of the Moroccan Educational System
}

\author{
Driss Harrizi \\ PhD student in Economic sciences \\ Faculty of Law, Economics and Social sciences \\ University Hassan 1st - BP 587 - Settat - Morocco \\ Laboratory of Mathematical Modeling and Computation of Economic "LM²CE"
}

\section{ABSTRACT}

System of Education and Training is a major lever in the development of Morocco, this awareness has made this system as the second priority after national territorial integrity.

Therefore, many projects have been implemented to reform the system of Education and Training. In this context, we discuss the National Charter of Education and Training representing the reference document benefiting from a general consensus for reform, the 2000-2010 decade was the decade of reform. The summary assessment of the reform shows that it is a " The Road Not Traveled "[1].

In order to accelerate reform of the System of Education and Training in Morocco, another program was designed and implemented for a period of four years from 2009 to 2012, this is the emergency program.

Starting from the design phase, and based on the experiences and everyday practices of its implementation, the present article aims to answer the following questions with a target of capitalization of experiences and a contribution to make the Education System Training and learning organization:

- How this program was developed?

- What are the objectives of the program,?

- What is it composed of?

- How it works?

- What are the achievements?
- Can we assess now?

- What to do next?

- What does the information represent in this approach?

- What are the lessons we can draw?

Keywords education and training system - Morocco - reform..

\section{INTRODUCTION}

The Moroccan Education System today is characterized by a large wave of reforms. Indeed, the July 30, 2007 speech of His Majesty King Mohamed VI drew the curtain on an alarming fact : the results of the reform of education and training have not been up to expectations and initial objectives of this reform: "It is therefore necessary to continue -before it's too late- the implementation of vital and unavoidable reforms, to strengthen good governance in this sector, and to find objective solutions to outstanding issues, with, primarily, the problem of financing, rationalization of resource management, language teaching, modernization programs and textbooks, and the focus on literacy. Furthermore, it is important to redouble efforts to successfully rehabilitate public schools and promote private education, while respecting the principle of "equal opportunity"[2]. The dissemination of the report of the World Bank on education reform in the countries of North Africa and Middle - East(2008) confirmed this 
observation by characterizing the education reform of "unfinished journey"[1].

On the other hand, the first annual report of the High Council of Education at the beginning of 2008 [3], pointed to the different structural dysfunctions of the national education system: hesitant governance of the education system, information system does not meet the requirements of an empowering management, lack of a comprehensive information system containing all information relating to education over several years and facilitating their use, high rates of dropout, repetition, poor quality of education program offered such as language skills and acquisition of skills in science ...

The alarm was pulled, the launching of educational reform project becomes an inevitable choice[4].

It is undeniable that education reform is a complex project; the organizational context of the education system itself is increasingly complex and changing.

Strong with a political will and supported by the highest authorities of the country, this reform should cover the whole education system, with all these subset.

It is through the special committee of education and training that Morocco has adopted in 1998, a real educational project of society: the National Charter of Education and Training. Education was then erected at the forefront of national priorities after Education[5]."

Ambitious project, the Charter addresses the educational reform from every angle including the reform of education management through effective decentralization / devolution to the regional and local institutions.

In order to reinvigorate the reform, "emergency program" was born over the period [2009-2012].

This project is a continuation of the reform, there is a new impetus and acceleration of the completion of the reform of the System of Education and Training.
As the education system has become the second priority behind the national territorial integrity, the government has allocated significant resources in support of reform, remains to control his spending in achieving the objectives.

\section{THE EMERGENCY PROGRAM}

For optimum efficiency, a new approach was adopted. Thus, the implementation of the Emergency Program 2009-2012 is based on an approach "Project". The policy of the Emergency Program is to place the learner at the heart of the System of Education and Training and to the other pillars to its service. The designers decided that the implementation of the Emergency Program will necessarily be a break with past practices, by adopting this new approach based on a Project Approach[6].

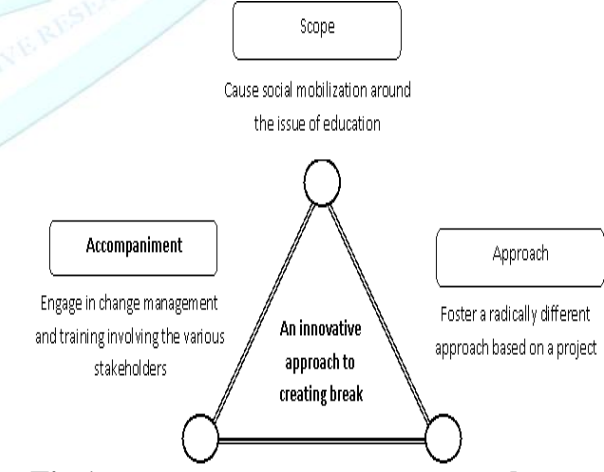

Fig 1 : emergency program approach[6]

Based on the priorities identified by the 2008 report of the SSC, the Emergency Program offers a program of action to address four key objectives which are the spaces of the emergency program including [7]:

Area 1: Make the effective compulsory education until the age of 15 years

Area 2: To stimulate the initiative and excellence in high school and university;

Area 3: Confronting the issues of crosssystem; 
Area 4: Providing the means to succeed is a determining factor.

For each area, a homogeneous set of projects are defined to seek consistency in the area, responding to common goals and broken down into specific action plans.

Table1. Portfolio of Emergency Plan 20092012 divided by Cluster: Summary

Version[7]

\begin{tabular}{|c|c|c|c|}
\hline Pole & $\begin{array}{c}\text { Project } \\
\text { Code }\end{array}$ & Project & \begin{tabular}{|c|}
$\begin{array}{c}\text { No. of } \\
\text { measur } \\
\text { es }\end{array}$ \\
\end{tabular} \\
\hline \multirow{7}{*}{ 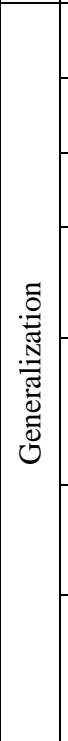 } & E1.P1 & $\begin{array}{c}\text { Preschool } \\
\text { development }\end{array}$ & 4 \\
\hline & E1.P2 & $\begin{array}{c}\text { Increased supply of } \\
\text { compulsory education }\end{array}$ & 2 \\
\hline & E1.P3 & $\begin{array}{c}\text { Upgrade } \\
\text { establishments }\end{array}$ & 5 \\
\hline & E1.P4 & $\begin{array}{c}\text { Equal opportunities } \\
\text { of access to } \\
\text { compulsory education }\end{array}$ & 3 \\
\hline & E1.P6 & $\begin{array}{l}\text { Promotion and } \\
\text { development of } \\
\text { physical education } \\
\text { and school sport }\end{array}$ & 3 \\
\hline & E1.P7 & $\begin{array}{c}\text { Fair for children and } \\
\text { communities with } \\
\text { special needs }\end{array}$ & 8 \\
\hline & E2.P1 & \begin{tabular}{|c|} 
Upgrade offer for \\
secondary qualifying \\
- High Schools \& \\
Internships
\end{tabular} & 5 \\
\hline \multirow{6}{*}{ 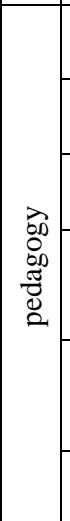 } & E1.P5 & $\begin{array}{c}\text { Fight against } \\
\text { repetition and dropout }\end{array}$ & 3 \\
\hline & E1.P8 & $\begin{array}{c}\text { Improvement of the } \\
\text { teaching }\end{array}$ & 14 \\
\hline & E1.P9 & Curriculum review & 4 \\
\hline & $\begin{array}{c}\text { E1.P1 } \\
0\end{array}$ & $\begin{array}{l}\text { Integration of ICT } \\
\text { and innovation in } \\
\text { learning }\end{array}$ & 5 \\
\hline & $\begin{array}{c}\text { E1.P1 } \\
1\end{array}$ & $\begin{array}{c}\text { Improving the system } \\
\text { of evaluation and } \\
\text { certification }\end{array}$ & 3 \\
\hline & $\begin{array}{c}\text { E1.P1 } \\
2\end{array}$ & $\begin{array}{c}\text { Improving the quality } \\
\text { of school life }\end{array}$ & 9 \\
\hline
\end{tabular}

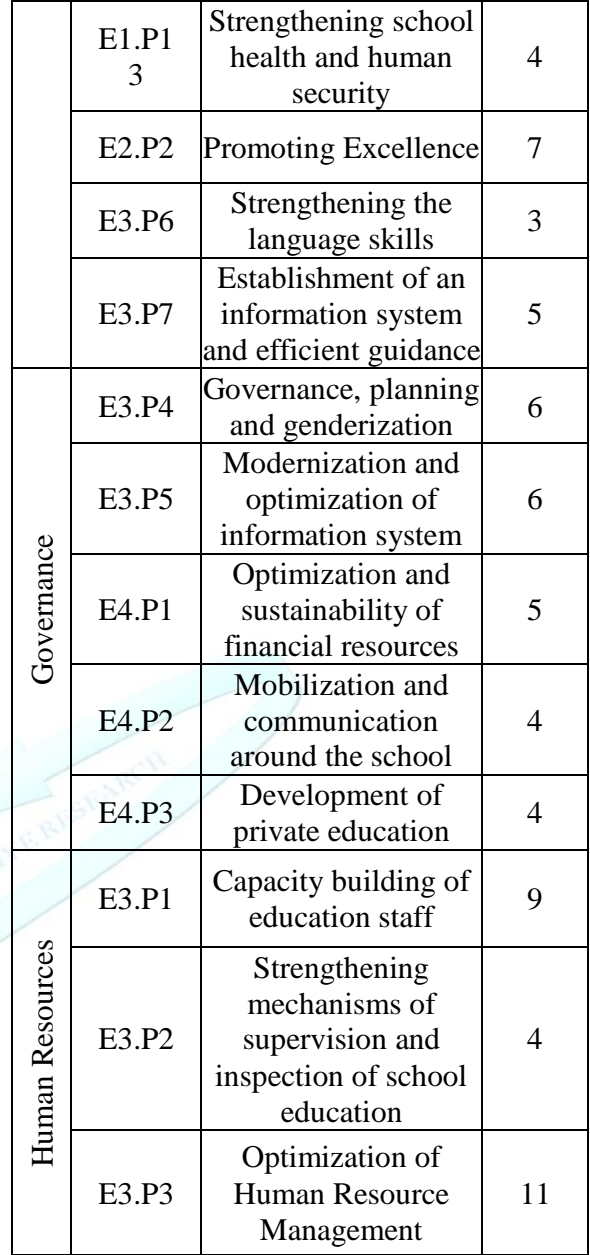

The operational implementation of the emergency program

Works for operationalization of the emergency program is divided into three key steps including:

- Data collection: Collection of data necessary for the establishment of the inventory.

- Feasibility Analysis: Definition of measures tools implementation

- Information sheet for operationalization: it is the central tool for the operational 
implementation of the Emergency

Program.

Five-day training was organized for all teams involved in the Emergency Program regarding:

- Project Management Tools and Methodology,

- Computer Fundamentals: Using the Office: MS Project, Access, Excel, etc.. and use of databases / applications for certain projects

- Communication Skills: Writing documents and Animation Meeting.

The Preliminaries

Table2. Components of the monitoring: Organization teams Emergency Program[7]

\begin{tabular}{|c|c|c|c|c|}
\hline$\stackrel{5}{\Phi}$ & 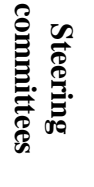 & 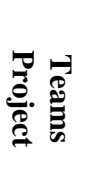 & 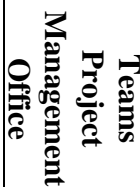 & 包 \\
\hline Central & $\checkmark$ & $\checkmark$ & $\checkmark$ & $\checkmark$ \\
\hline Regional & $\checkmark$ & $\checkmark$ & $\checkmark$ & \\
\hline Provincial & & $\checkmark$ & & \\
\hline
\end{tabular}

\section{CRITICAL ANALYSIS}

During its initial phase, the emergency program has had benefits from significant financial funds and strong support from senior levels.

Its implementation has been gradual; waves of projects were launched with a time shift more or less important.

The great problem of evaluating the education system has not been resolved and the use of a consistent set of indicators without common understanding on the part of all stakeholders, has not resolved this difficulty. There is excessive use of the term average, and since the latter is often misleading indicators no longer reflect the true picture of the phenomenon in question.
We present above the main constraints and remarks raised by the practice and the implementation of the emergency program:

Design: The use of a private company for the design of the emergency program remains a debatable choice, intelligence and internal memory of the education system were inhibited. An inventory of internal expertise and capitalization of past experiences and information from past projects (international cooperation projects: Procadem - Usaid-alef - ...) could help to better handle the design.

Participation: the participation of all stakeholders from different levels in different phases of the emergency program from design, implementation and evaluation has been limited. For example, faculty and administrative staff of educational institutions and education were rarely involved. Consequently, many actors in the program were not able to deal with measures requirements for some projects within the emergency program.

A Fragmented implementation: the launch of the emergency program projects, in wave has resulted in a shift risk to the overall vision of this program, as several projects are dependent and that the pace of progress of a project affects on the other.

The information system: information system of education has not been of support to the achievement of the emergency program. It is always oriented businesses, segmented and does not meet the requirements of the reform. It could not adapt to changes and challenges met by the Moroccan educational system[8].

Actors: the implementation of the emergency program has required the involvement of many actors inside the system. An engagement letter for each type of actor, defining their powers and their scope and relationships with others has never been possible, which left the way for voluntarism and personal will. This includes a risk. A mechanism for coordination and monitoring of all stakeholders would facilitate the proper conduct of stakeholder participation at all levels of the system. 
Partners participation: Despite the national scope of the reform of education and training, the approach of the emergency program remained sectoral. Participation, contribution and input of other actors, external to the system and other sectors and departments of the nation is very limited and below expectations.

The budget: the scheduling of the objectives of the emergency program was defined on a multi-year basis, through a reference document called "the action plan in the medium term" that was not defined aver the same period. A approved framework for medium term expenditure could give more visibility and realism in this program.

Human resources: If significant financial resources have been mobilized at the beginning of the emergency program, the Human Resources component remained in the shade. Despite official rhetoric, there is no team dedicated solely to the emergency program, therefore the team members are left with two statutes, a function in the program team and other administrative functions outside the program (formal organization before the birth of the emergency program and is still outstanding).

The emergency program claims to accelerate the pace of reform and change the mode of project management using the same resources in number and profiles. A scarcity of several types of profiles is clearly noticed in the system of education and training. To this is added the effects of human resource mobility. House-expertise in project management are very limited or even absent, and training actions performed were not enough to fulfill this lack of competencies.

We believe that the Human factor is key factor among the main factors of success of the reform of education and training.

Legal framework: The education system and training exercises currently in two opposite modes: a traditional but official organization of the education system and an organization in project mode as proposed by the emergency program, without any change in the legal framework governing the system of education and training. This situation caused several overlaps and conflicts. A new organizational chart in a matrix structure specific to the education and training system should be adopted and fix this issue. An update of laws organizing the system of education and training is crucial to adapt the system to this new context and avoid administrative delays.

The measurement and assessment: they are notably the main absent in the Moroccan system of education and training. The measurement and assessment are still problematic issues to be answered. Several attempts have been made but the problem remains. Naturally, the assessment is part of a perspective of judgment and decision making of learning, lessons or programs. The measurement and assessment are major issues in the reform of Moroccan education and training. Thus, assessment models, assessment policy, evaluation devices, evaluation of learning must be subject to deep reflexion and consensus, to help at the end of this process to building a quality system specific to education and training in Morocco.

Communication: despite efforts in the communication and awareness campaign around the emergency program, we note that this communication is limited in performance, since it applies only to internal actors in the system through punctual actions and using a single mode of communication. Partners and external stakeholders of the system, that could give a plus to the emergency program have not been covered by this communication.

Communication channels between the different actors of the emergency program and system levels are made by traditional means. A dedicated communication platform seems to strengthen the communication between actors.

A technical approach: a special passion for tech is noticed in the operationalization of the emergency program. In addition, formalism settled, and focus was made on the 
completion of the monthly reporting rather than the achievement of results.

The reporting tools adopted do not reflect the level of effort in achieving the goal of each project and measure. The was a confusion between the outcome and monitoring indicators. Readjustments during the journey are rare in all projects.

Teams of the emergency program are struggling to overcome a tremendous and endless workload. The multiplicity of reporting documents and their complexity, the traditional tool (Ms-Excel and MS-Word) and continuous research to produce information in the absence of an adequate information system, led the emergency program teams to work in a permanent stress and inefficiency.

Pedagogy: Pedagogy aspect and more precisely, the determining relationship "between teacher and student" remained uncontrollable and out of scope of the emergency program. The emphasis is on hardware components in term of equipment and buildings in particular, which remain support means to the primary purpose of the system, which is "the act of teaching". The latter had no place in the emergency program and many projects related have not been implemented so far.

The school project: the convergence of various projects of the emergency program at the local level has not been possible in the "school plan" for each school, and college. Different measures have remained segmented and do not fit with the proposed development of the school. It was also noted the noncompetitive bidding between different institutions and structures of the system.

The environmental monitoring: recording the absence of mechanisms and tools for environmental monitoring system of education and training. The watch activity is almost absent.

\section{CONCLUSION}

The environment of this system has been changing rapidly and sometimes radically, resulting in a need of environmental monitoring system on the Education and Training. The concept of strategic management is needed more than ever and at all levels.

Experience during the operationalization of the various projects of the emergency program has shown the crucial role of information in the good governance of the system of education and training. It became the heart of the strategy of this system. The various actors in the system are called to change their behavior towards information and improve their practices. The basic idea which we need to share is information, past experiences and the best practices are also vectors of development system. They are changing and increasing our knowledge and intelligence (knowledge and experience)[9].

The size and complexity of the system of education and training are now such that it is difficult to identify experts and other knowledge holders within that system. In addition, the evolution of the system in its environment and its new stakes external forcing this to be much more efficient than in the past, to share and capitalize experiences not to "reinvent the wheel" with each new project. The system of education and training must necessarily move from individual intelligences to collective intelligence, at this stage we can speak of a learning organization where knowledge management and watch system are key elements in the service of strategic management of the education system Moroccan and training.

We think that the System of Education and Training in Morocco was not yet ready and available for such a program with twenty-six projects. Prior to launching such large-scale projects, preliminary measures are necessary to prepare the adequate information system and upgrade the human resources.

To conclude, we understand at the end of the emergency program for the reform of education training Moroccan, that all is not the sum of its parts. 


\section{REFERENCES}

[1] The International Bank for Reconstruction and Development / The World Bank.2008. The Road Not Traveled Education Reform in the Middle East and North Africa.http://siteresources.worldbank.or g/INTMENA/Resources/EDU_Flagship _Full_ENG.pdf, accessed January 2012. Washington, USA .2008.

[2] King Mohamed VI .Royal speech . July 30, 2007.2007.

[3] High Council of Education .2008. The first annual report of the High Council of Education, statement and prospects of the System of Education and Training. Morocco.2008.

[4] Sobhi.T, Sophie C, Amapola A. 2010 .éducation au Maroc: analyse du secteur. UNESCO. Cluster Office for North Africa, 2010.

[5] National Charter for Education and Training.2000. Morocco.2000.

[6] Minister of Education. 2009. Summary Report of the emergency program 20092012, Morocco.

[7] Documentation of the Moroccan Ministry of National Education on the emergency program on the web address: www.men.gov.ma, accessed January 2009.

[8] Jacques.L, Driss.H. 2008. Critical Analysis of Statistical Information System of Education. thesis work for access to the rank of chief engineer. Minister of Education Morocco. May 2008.

[9] S.Mullender,Riccardo.V,Henry.E.2010. The Capitalization of KnowledgeATriple Helix of University-IndustryGovernment. Edward Massachusetts: Elgar Publishing, Inc.2010. 